\title{
Correction to: Assessing Improvement of Patient Satisfaction Following Facelift Surgery Using the FACE-Q Scales: A Prospective and Multicenter Study
}

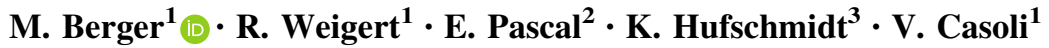

Published online: 22 May 2019

(C) Springer Science+Business Media, LLC, part of Springer Nature and International Society of Aesthetic Plastic Surgery 2019

\section{Correction to: Aesth Plast Surg (2019) 43:370-375}

https://doi.org/10.1007/s00266-018-1277-9

The Electronic Supplementary Material originally published with this article has been removed due to lack of appropriate permissions from the copyright holder.

The original article can be found online at https://doi.org/10.1007/ s00266-018-1277-9.

M. Berger

berger.mailys@gmail.com; mailys.berger@chu-bordeaux.fr

1 Department of Plastic and Reconstructive Surgery, Hand Surgery, Burns Unit, FX Michelet Center, University Hospital Bordeaux, Place Amélie Raba-Léon, 33076 Bordeaux, France

2 Department of Maxillofacial and Oral Surgery, FX Michelet, University Hospital Bordeaux, Place Amélie Raba-Léon, 33076 Bordeaux, France

3 Department of Plastic and Reconstructive Surgery, University Hospital Nice, Pasteur 2, 30, Avenue de la Voie-Romaine, 06000 Nice, France 